DOI https://doi.org/10.30525/978-9934-588-81-5-1.46

\title{
ДОСЛІДЖЕННЯ РОЗПОДІЛУ УРОПАТОГЕНІВ СЕРЕД ХІРУРГІЧНИХ ТА СОМАТИЧНИХ ПАЦІЕНТІВ ВІДДІЛЕННЯ ІНТЕНСИВНОЇ ТЕРАПІЇ ДИТЯЧОЇ КЛІНІКИ
}

\author{
Садова-Чуба 3. Т.
}

асистент кафедри анестезіологї та інтенсивної терапії

Львівський національний медичний університет імені Данила Галиџького

Слаба О. Р.

кандидат медичних наук, асистент кафедри внутрішньої медицини № 2

Львівський начіональний медичний університет імені Данила Галицького

Василів М. В.

асистент кафедри анестезіологї та інтенсивної терапії

Львівський національний медичний університет імені Данила Галицького м. Львів, Украӥна

Згідно останніх епідеміологічних даних, нозокоміальні інфекції сечової системи (НICC) є другими за частотою після нозокоміальних інфекцій нижніх дихальних шляхів. Хоча, ще двадцять років тому інфекції сечовидільних шляхів займали перше місце у цій групі. На їх долю припадає близько 44\% від загального числа внутрішньо лікарняних інфекцій.

За даними Європейського епідеміологічного дослідження ESGNI $(1,2$, с. 3), частота нозокоміальних інфекцій сечовидільних шляхів становила 3,55 випадки на 1000 пацієнто-дні. Найчастіше ці інфекції виникали у ВІТ, а також в урологічних та неврологічних відділеннях. За даними дослідження ЕРIC II $(3,4$, с.3), у відділеннях інтенсивної терапії (ВIT) країн Східної Свропи інфекцій сечових шляхів складають 19,7\% від усієї захворюваності. Поширеність нозокоміальних інфекцій сечових шляхів в урологічних відділеннях складало 10\% $(4,5$, с. 4$)$, домінувала серед них безсимптомна бактерійурія (29\%), катетер-асоційований цистит (26\%) та пієлонефрит (21\%).

Хоча НICC меншою мірою впливають на прогноз та підвищення ризиків смерті пацієнтів у стаціонарі в порівнянні з іншими інфекціями (пневмонія, перитоніт), слід відзначити, що 15-20\% випадків НІСС супроводжуються бактерійурією, що підвищує атрибутивну летальність на 4-30\% ( 6, 7, с. 4). 
Було обстежено 48 пацієнтів, яких ми поділили на дві групи. Групу 1а становили пацієнти 3 хірургічною патологією, котрим сечовий катетер Фолея встановлювали в умовах операційної дотримуючись усіх правил постановки сечового катетера визначених наказом МO3 № 460 від 01.06.2013, кількість пацієнтів цієї групи 18. Групу 2 становили пацієнти з соматичною патологією котрим сечовий катетер Фолея встановлювали у відділені інтенсивної терапії, дотримуючись тих самих правил постановки катетера і асептики зокрема, кількість пацієнтів цієї групи 30.

Мікробіологічний посів сечі проводили на третій та п’ятий день катетеризації сечового міхура, також проводили мікробіологічний посів 3 кінчика сечового катетера, після його видалення. Забір матеріалу проводили згідно наказу охорони здоров’я України від 10.05.2007 № 234, сечу забирали 3 катетера, попередньо його перекривши і від'єднавши від сечоприймача, матеріал для дослідження доставляли у лабораторію, якнайшвидше, протягом 30 хвилин, але не довше 2 годин.

В групі 1 Escherichia coli мала частку 3,64\%, Klebsiella pneumoniae $5,45 \%$, Enterococcus spp. 5,45\%, Pseudomonas aeruginosa 7,27\%, Candida albicans мала найбільшу частку 12,73\%, Staphylococcus epidermidis $1,82 \%$. В групі 2 найбільшу частку мали Pseudomonas aeruginosa $12,73 \%$ i Candida albicans $23,64 \%$, менші частки були у Escherichia coli 7,27 \%, Klebsiella pneumoniae 10,91\% та Enterococcus spp. 7,27 \%, \%, найменша частка була у Staphylococcus epidermidis $1,82 \%$ (таблиця 1.)

Таблиця 1

Етіологічна структура катетер-асоційованих інфекцій хірургічних та соматичних паціснтів, що потребують інтенсивної терапії

\begin{tabular}{|c|c|c|c|c|}
\hline \multirow{2}{*}{$\begin{array}{c}\text { Вид } \\
\text { мікроорганізму }\end{array}$} & \multicolumn{2}{|c|}{$\begin{array}{c}\text { Група 1а } \\
\text { (хірургічні) } \mathbf{n = 1 8}\end{array}$} & \multicolumn{2}{c|}{$\begin{array}{c}\text { Група 2a } \\
\text { (соматичні) } \mathbf{n = 3 0}\end{array}$} \\
\cline { 2 - 5 } & $\begin{array}{c}\text { абсолютна } \\
\text { кількість }\end{array}$ & $\%$ & $\begin{array}{c}\text { абсолютна } \\
\text { кількість }\end{array}$ & $\%$ \\
\hline Escherichia coli & 2 & $3.64 \%$ & 4 & $7.27 \%$ \\
\hline $\begin{array}{c}\text { Klebsiella } \\
\text { pneumoniae }\end{array}$ & 3 & $5.45 \%$ & 6 & $10.91 \%$ \\
\hline Enterococcus spp. & 3 & $5.45 \%$ & 4 & $7.27 \%$ \\
\hline $\begin{array}{c}\text { Pseudomonas } \\
\text { aeruginosa }\end{array}$ & 4 & $7.27 \%$ & 7 & $12.73 \%$ \\
\hline Candida albicans & 7 & $12.73 \%$ & 13 & $23.64 \%$ \\
\hline $\begin{array}{c}\text { Staphylococcus } \\
\text { epidermidis }\end{array}$ & 1 & $1.82 \%$ & 1 & $1.82 \%$ \\
\hline
\end{tabular}


Помітно, що кількість отриманих позитивних посівів суттєво більша у групі 2, у порівнянні з групою 1. Найчастіше виявили Candida albicans. Серед грамнегативних бактерій як у групі 1 так і в 2 переважає Pseudomonas aeruginosa та Klebsiella pneumoniae. Серед грампозитивних бактерій переважала Enterococcus spp. Проаналізуваши етіологічну структуру катетерасоційованих інфекцій сечових шляхів у хірургічних та соматичних пацієнтів BIT, ми побачили дещо вищий рівень позитивних бактеріологічних посівів у соматичній групі, проте, дана різниця не $\epsilon$ статистично значимою.

\section{Література:}

1. 1.Preventing hospital-acquired urinary tract infection in the United States: a national study / Saint S., Kowalski C. P., Kaufman S. R., et al. // Clin. Infect. Dis. 2008. Vol. 46, № 2. P. 243-253.

2. A Guide to Infection Control in the Hospital. An official publication of the International Society for Infectious Diseases / Edit.: R. Wenzel, T. Brewer, J-P. Butzler. B. C. Decker. $2^{\text {nd }}$ Edition. London : Inc Hamilton, 2002. 245 p.

3. Саркулова М. Н. Характер и этиологическая структрура внутрибольничной инфекции у урологических больних // Урология. 2006. № 1. C. 19-22.

4. The Global Patient Safety Challenge: 2005-2006 / World Alliance for Patient Safety. Geneva : World Health Organization, 2005. 25 p.

5. Di Pietrantoni C., Ferrara L., Lomolino G. Multicenter study of the prevalence of nosocomial infections in Italian hospitals // Infect. Control Hosp. Epidemiol. 2004, Vol. 25, № 1. P. 85-87.

6. Stone P. W., Braccia D., Larson E. Systematic review of economic analyses of health care-associated infections // Am. J. Infect. Control. 2005. Vol. 33, № 9. P. 501-509.

7. National Healthcare Safety Network (NHSN) Report, data summary for 2006 through 2007, issued November 2008 / Edwards J. R., Peterson K. D., Andrus M. L. et al. // Am. J. Infect. Control. 2008. Vol. 36, № 9. P. 609-626. 